\title{
Seasonal variation of peroxyacetylnitrate (PAN) in coastal Antarctica measured with a new instrument for the detection of sub-part per trillion mixing ratios of PAN
}

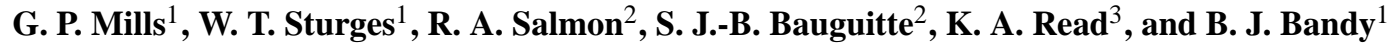 \\ ${ }^{1}$ School of Environmental Sciences, University of East Anglia, Norwich NR4 7TJ, UK \\ ${ }^{2}$ British Antarctic Survey, Maddingley Road, Cambridge, UK \\ ${ }^{3}$ Department of Chemistry, University of York, Heslington, York YO19 4RR, UK
}

Received: 5 April 2007 - Published in Atmos. Chem. Phys. Discuss.: 26 April 2007

Revised: 20 August 2007 - Accepted: 4 September 2007 - Published: 7 September 2007

\begin{abstract}
An automated gas chromatograph with sample pre-concentration for the measurement of peroxyacetylnitrate (PAN) was constructed with a minimum detection limit below 1 pptv. This instrument was deployed at the British Antarctic Survey's Halley Research Station, Antarctica $\left(75.6^{\circ} \mathrm{S}, 26.6^{\circ} \mathrm{W}\right)$ as part of the CHABLIS (Chemistry of the Antarctic Boundary Layer and the Interface with Snow) campaign. Hourly measurements were carried out between July 2004 and February 2005 with observed maximum and minimum mixing ratios of 52.3 and $<0.6 \mathrm{pptv}$, respectively with a mean PAN mixing ratio for the measurement period of $9.2 \mathrm{pptv}$ (standard deviation: $6.2 \mathrm{pptv}$ ). The changes in PAN mixing ratios typically occurred over periods of several days to a week and showed a strong similarity to the variation in alkenes. The mixing ratio of PAN at Halley has a possible seasonal cycle with a winter maximum and summer minimum, though the cycle is incomplete and the data are very variable. Calculations indicate that gross local PAN production is approximately $1 \mathrm{pptv} \mathrm{d}^{-1}$ in spring and $0.6 \mathrm{pptv} \mathrm{d}^{-1}$ in summer. Net loss of PAN transported to Halley in the summer is a small gas-phase source of NOx and net production of PAN in the spring is a very small NOx sink.
\end{abstract}

\section{Introduction}

One of the products of the oxidation of most hydrocarbons by $\mathrm{OH}$ radicals in the presence of $\mathrm{NO}_{2}$ is peroxyacetylnitrate $\left(\mathrm{CH}_{3} \mathrm{C}(\mathrm{O}) \mathrm{OONO}_{2}\right)$, hereafter referred to as PAN, which is the most abundant of a number of peroxy nitrates which have been observed in the troposphere (Roberts 1990, Roberts et al., 2003; Flocke et al., 2005).

Correspondence to: G. P. Mills

(g.mills@uea.ac.uk)
Since its discovery as a component of photochemical smog, PAN has been measured throughout the troposphere, even in remote locations. The mixing ratios of PAN seen in highly polluted urban environments can reach tens of parts per billion (ppbv) (Gaffney et al., 1999; Rappengluck et al., 2000) whilst the levels seen in remote marine environments are often only a few pptv (Gallagher et al., 1990; Muller and Rudolph, 1992; Staudt et al., 2003)

While the production of the peroxyacetyl (PA) radical (which reacts with $\mathrm{NO}_{2}$ to make PAN) is a photolytic process, the main loss process for PAN is initiated by dissociation into the peroxyacetyl radical and $\mathrm{NO}_{2}$. This dissociation process is highly sensitive to temperature, so much so that a change in temperature from $300 \mathrm{~K}$ to $270 \mathrm{~K}$ changes the calculated rate of dissociation by over two orders of magnitude. Thus PAN produced in polluted environments and lifted to high altitudes, where the temperatures are low, could be transported great distances before the air descends and warms, releasing the $\mathrm{NO}_{2}$ tied up in PAN. This transport of PAN away from source regions and its subsequent thermal decomposition has long been a subject of interest as a source of nitrogen oxides (NOx), and thus a potential impact on ozone production, in remote regions (Crutzen, 1979; Ridley et al., 1990, Hudman et al., 2004).

While there have been many studies of PAN in remote northern hemisphere locations, with several of the arctic (Bottenheim and Gallant, 1989; Beine and Krognes, 2000; Dassau et al., 2004), there are fewer published studies of the southern hemisphere and only currently two of high southern latitudes.

Measurements made during the PEAN'99 campaign show PAN mixing ratios at Neumayer $\left(70.6^{\circ} \mathrm{S}, 8.3^{\circ} \mathrm{W}\right)$ ranging between $48 \mathrm{pptv}$ and $<5 \mathrm{pptv}$ (the limit of detection) during February (Jacobi et al., 2000). This campaign was followed by a cruise north from Neumayer to Cape Town, South Africa in March and there was only 1 pptv variation in the observed daily mean PAN mixing ratios of $17.6 \mathrm{pptv}$ at latitudes

Published by Copernicus Publications on behalf of the European Geosciences Union. 
A

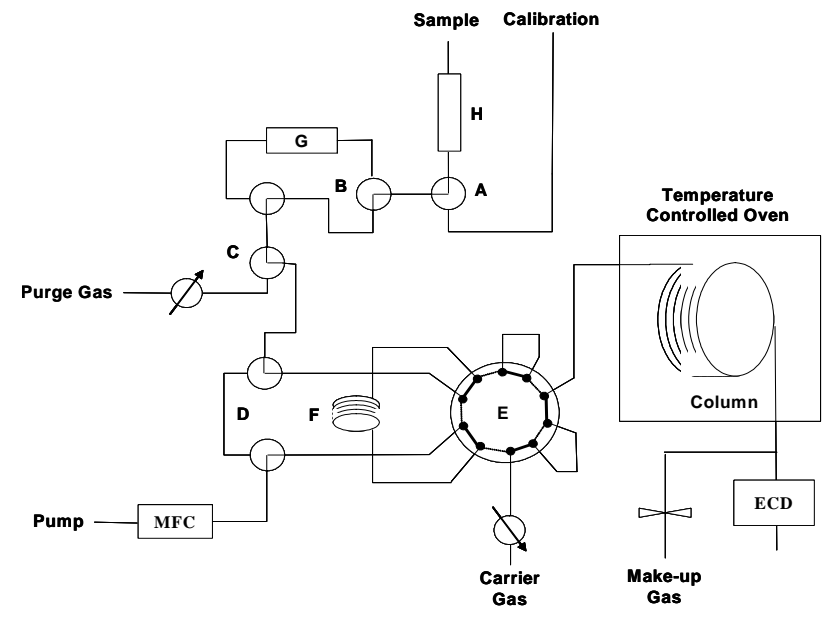

B

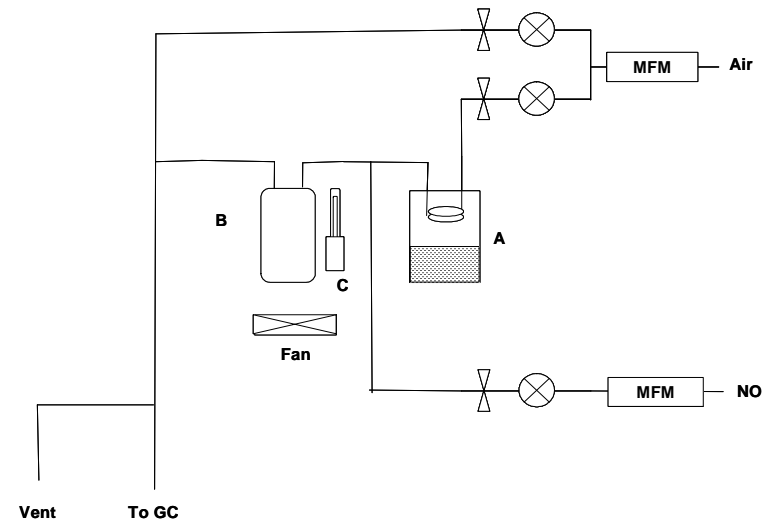

Fig. 1. (A) schematic of the gas chromatograph showing calibration selection valve (A), zero valve (B), start/stop/purge valve (C), bypass valves $(\mathrm{D})$, VICI valve $(\mathrm{E})$, the cooled sample trap $(\mathrm{F})$, the heated tube for performing zeros $(\mathrm{G})$ and the nafion Dryer $(\mathrm{H})$. (b) Schematic of the calibration unit. (A) acetone reservoir, $(\mathrm{B}+\mathrm{C})$ photolysis cell and penray lamp. MFM is a mass flow meter.

between $60^{\circ} \mathrm{S}$ and $70^{\circ} \mathrm{S}$ (Jacobi and Shrems, 1999). However, since both studies were limited to the late austral summer we have no seasonal information.

This study aims to add to the exceptionally sparse measurements of PAN so far reported in the Antarctic region and to investigate any seasonality of PAN mixing ratios in Antarctica. In this paper we present measurements taken over the austral winter, spring and summer of 2004-2005, made with a purpose built automated gas chromatograph which we describe.

\section{Experimental}

\subsection{Measurement site}

All the measurements used in this study were taken at the Clean Air Sector Laboratory (CASlab) at Halley located on the Brunt ice shelf, Antarctica. The predominant wind direction at Halley is easterly, with westerly and more southerly winds also contributing a significant proportion of surface wind directions seen at Halley (King, 1985; Renfrew and Anderson, 2002). Northerly winds are rare. The CASlab itself was situated approx. $1 \mathrm{~km} \mathrm{SSE}$ from the main base.

The CASlab sample manifold consisted of an unheated inlet approximately $8 \mathrm{~m}$ above the surface, connected to a $10 \mathrm{~cm}$ diameter stainless steel pipe from which the instrument sampled via a $2 \mathrm{~m}$ long $1 / 8$ " PFA line.

Measurements of ozone, $\mathrm{CO}$ and non-methane Hydrocarbons (NMHC) were made throughout the PAN measurement period, while measurements of $\mathrm{NO}$ and $\mathrm{NO}_{2}$ data were available for January and February only. Ozone was measured every minute using a commercial UV absorption instrument (2B Technologies). NMHC were measured on an hourly basis using a GC-FID with pre-concentration of samples on an adsorbent trap (Read et al., 2007), with detection limits in the range $2-5 \mathrm{pptv}$ for $\mathrm{C}_{2}-\mathrm{C}_{5}$ hydrocarbons. $\mathrm{CO}$ was measured as a $30 \mathrm{~s}$ average using a commercial fast-response resonance fluorescence instrument (Aerolaser $\mathrm{GmbH}$ ). $\mathrm{OH}$ and $\mathrm{HO}_{2}$ radicals were also measured during the summer intensive period (late December to early February) using the FAGE technique (Bloss et al., 2007).

\subsection{Instrument description}

The GC used in this study was a 19" rack mounted computer controlled instrument and a schematic is shown in Fig. 1a. This schematic does not show details of the trap itself or the temperature controls.

\subsubsection{Sample trap}

The sample trap consists of a $1 \mathrm{~m}$ coil of $0.53 \mathrm{~mm}$ MxT-1 (100\% dimethylpolysiloxane) metal column (Restek) with a film thickness of $7 \mu \mathrm{m}$. The coil was contained inside a circular groove cut into a $3 \times 3 \times 0.5 \mathrm{~cm}$ aluminium block and held in the groove by an aluminium plate. The block was cooled to between $223 \mathrm{~K}$ and $208 \mathrm{~K}$ using a triple stage cascade peltier (Melcor CP1.0-127-05L operated at $6 \mathrm{~V}$ on top of a Melcor 2SC055045-127-63L running at $13 \mathrm{~V}$ ) with a water cooled heatsink maintained at $263 \mathrm{~K}$ by a re-circulating water chiller. The temperatures of the aluminium block and the sample loop were recorded with T-type thermocouples. The cold block was insulated and sealed to prevent water condensing on the trap.

For injections, the sample loop was heated by passing a current directly through the sample loop using a $12 \mathrm{~V} \mathrm{DC}$ supply. The heating of the sample loop was controlled by 
computer and heating rates of approximately $14^{\circ} \mathrm{C} \mathrm{s}^{-1}$ were used. An injection temperature of $308-318 \mathrm{~K}$ was used to minimise the thermal decomposition of PAN in the sample loop.

\subsubsection{Column and column oven}

The column was a $15 \mathrm{~m}$ long $0.25 \mathrm{~mm} \mathrm{i} / \mathrm{d}$ MXT-200 (trifluoropropylmethyl polysiloxane) with a $1 \mu \mathrm{m}$ film (Restek) which was housed in a temperature programmable oven. The column was held at $263 \mathrm{~K}$ for $3 \mathrm{~min}$ and then heated up to $318 \mathrm{~K}$, initially at $1.3 \mathrm{~K} \mathrm{~min}^{-1}$ and then after PAN had eluted, at $5 \mathrm{~K} \mathrm{~min}^{-1}$. Under typical operating conditions, PAN eluted after $12 \mathrm{~min}$. The oven consisted of an insulated $1.3 \mathrm{~cm}$ thick aluminium block with a $10 \mathrm{~cm}$ diameter circular groove cut into it, into which the column sat and was held tightly in place by a covering plate. The block was cooled with a $58 \mathrm{~W}$ single-stage Peltier device and heated on the opposite side by a $50 \mathrm{~W}$ mat heater attached to the covering plate. The temperature of the column was measured in 3 places by k-type thermocouples to ensure an even temperature along the column. Maximum and minimum possible temperatures of the column were limited by temperature controllers and temperatures within this range were regulated by turning the heater/peltier combination on and off as necessary.

\subsubsection{Sample manifold and zeros}

The sample manifold consisted of six 3-way PTFE solenoid valves connected by silcosteel tubing (Restek). The sample manifold was flushed with sample air for 3 min before trapping started by actuating two bypass valves (D in Fig. 1) and the purge valve (C). Trapping was initiated by deactivating valves (D) and terminated by deactivation of valve (C). Because of the small diameter of the trap, the amount of water in $200 \mathrm{ml}$ of Antarctic air could block the trap so the air samples were dried with a 72" nafion dryer $(\mathrm{H})$ situated upstream of valve (A). All samples were trapped for $10 \mathrm{~min}$ at $20 \mathrm{sccm}$ and purged with helium for $20 \mathrm{~s}$ prior to injection to reduce the disruption to the baseline caused by the oxygen in the sample.

Calibrations were performed by actuating valve (A) which selects the output from the calibration unit and zeros were performed by diverting the sample flow through a $3 \mathrm{~m}$ length of $1 / 8$ " silcosteel tubing wound onto an aluminium block $(\mathrm{G})$ maintained at $423 \mathrm{~K}$, a method commonly used in PAN instruments. At this temperature $99.9 \%$ of PAN should have dissociated in $0.14 \mathrm{~s}$ and at sample flow rate of $20 \mathrm{sccm}$ the residence time in the tube is approx. $14 \mathrm{~s}$. Bare stainless steel tubing was not used to avoid possible decomposition of propyl nitrate, which co-elutes with PAN on this column, on dry metal. Propyl nitrate should not thermally decompose at this temperature because it has a lifetime of over $2 \mathrm{~h}$ at $420 \mathrm{~K}$ based on the thermal dissociation rate constant of Barker et al. (1977).

All gases were drawn through the trap with a diaphragm pump and the flow rates were controlled by a downstream mass flow controller between the trap and the pump.

\subsubsection{Others}

The carrier and purge gases (both Helium) were regulated by pressure regulators and the detector make up gas ( $\mathrm{Ar}-$ $\mathrm{CH}_{4}(5 \%)$ ) was controlled by a stainless steel double stage needle valve. Typical operating conditions were a column flow rate of 1-2 ml min ${ }^{-1}$ and a makeup gas flow of $25 \mathrm{ml}$ $\min ^{-1}$

The detector was a CE80 Electron capture detector (Thermo Scientific) controlled with an ECD850 control unit (Thermo Scientific). The detector was held at $329 \mathrm{~K}$ to minimise PAN decomposition in the detector, which was significant at a detector temperature of $350 \mathrm{~K}$

Data was acquired using custom written software and Measurement Computing hardware and data was sampled at $81 \mathrm{~Hz}$ and averaged and recorded at $9 \mathrm{~Hz}$.

\subsubsection{Calibration unit}

The calibration unit produces PAN using the widely used method of photolysis of acetone/air/NO mixtures (Warneck and Zerbach, 1992; Flocke et al., 2005). A schematic of the calibration unit is shown in Fig. $1 b$.

Acetone-containing air $\left(50-100 \mathrm{ml} \mathrm{min}^{-1}\right)$ is mixed with NO (flow $0.5-2 \mathrm{ml} \mathrm{min}^{-1}$ ) and the mixture is photolysed in a flow-through Pyrex cell. A Penray mercury lamp was employed and the Pyrex cell cuts out wavelengths below 290 $\mathrm{nm}$, preventing photolysis of PAN in the cell. This minimises PAN photolysis within the cell, but requires a higher acetone concentration for maximum conversion of NO to PAN than the method of Flocke et al. (2005). The acetone containing air was generated by passing air through silicone tubing held above an acetone reservoir and the length of the silicone tube was optimised to minimise the amount of acetone required for maximum PAN production. The PAN produced in the photolysis cell is then further diluted by zero air, the flow of which is controlled by a flow control valve. The total air flow (acetone permeation + diluent) was measured upstream with a mass flow meter.

The lamp and the upstream solenoid on/off valves were controlled by PC allowing automatic selection of a variety of calibration unit outputs (zero air, non-photolysed mixture etc).

Prior to the field deployment, the output of the calibrator was analysed on a 4 channel chemiluminescence NOxy instrument (Brough et al., 2003) and a GC-ECD optimised for organic nitrate analysis (Jones et al., 1999). Within the calibration unit greater than $99.5 \%$ NO loss was observed, with approx. $1 \%$ of the NOy output being methyl nitrate. Because 

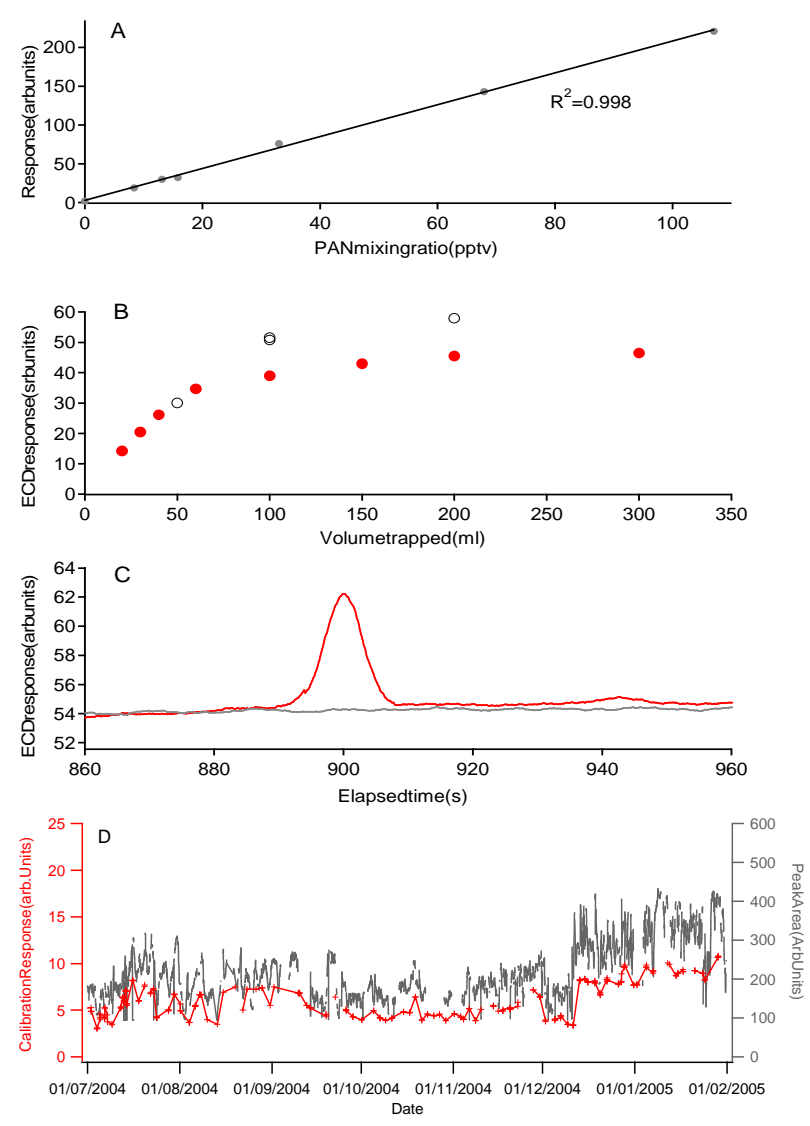

Fig. 2. (A) Response of the instrument to $200 \mathrm{ml}$ samples of different PAN mixing ratios trapped at $223 \mathrm{~K}$ (B) The response of the instrument to different sample volumes at two temperatures, $210 \mathrm{~K}$ (black-open) and $223 \mathrm{~K}$ (red-solid) (C) Two chromatograms of Antarctic air taken on 11 December 2004 containing 31 pptv of PAN (red line), and after passing through zero heater (grey line). (D) Timeseries of calibration-derived instrument sensitivity (redmarkers) and area of peak X (probably mostly $\mathrm{CCl}_{4}$ ) from air samples obtained during the deployment in Halley.

of the presence of acetone, the $\mathrm{NO}_{2}$ could not be determined very accurately with this instrument, but was estimated at only $3-4 \%$ of the total NOy. We thus estimate that the calibration source converts NO to PAN with about a $95+/-2 \%$ efficiency. The accuracy in the calibration output, as calculated from the sum of the squares of the individual errors in gas flows, conversion efficiency and the NO mixing ratio, is estimated to be $14.2 \%$. The NO standard used by the calibrator was re-analysed post campaign and was found to be $2 \%$ lower than its pre-campaign certification level (E. Williams, personal communication).

\section{Results and discussion}

\subsection{Instrument performance}

To test if the instrument response was linear with concentration, $200 \mathrm{ml}$ samples of calibration gas with PAN mixing ratios between 8 and 107 pptv were trapped at $223 \mathrm{~K}$. A sample of photolysed air/acetone (NO not added) was also measured. It is clear from Fig. 2a that the instrument is linear over the range studied.

Figure $2 \mathrm{~b}$ shows the detector response to a calibration of 20 pptv as a function of sample volume at two trapping temperature ( 210 and $223 \mathrm{~K}$ ). As can be seen, the instrument response is linear for small sample volumes, but flattens out at higher volumes indicating that sample breakthrough has occurred and that at $200 \mathrm{ml}$ the trap has reached equilibrium with the sample air. At $223 \mathrm{~K}$ the curve starts to become nonlinear at a lower sample volume and the instrument response is lower at high sample volumes indicating a smaller effective volume of air is concentrated at $223 \mathrm{~K}$ than at $210 \mathrm{~K}$. This suggests that variations in trap temperature could thus result in inaccurate PAN measurements. During the measurement period, the fluctuations in trap temperature were observed mainly in the winter when the laboratory temperature fluctuated most. These occurred over periods of several days and since calibrations were performed during these periods the change in temperature and thus effective sample volume should not have given spurious results. There was however a drift in the minimum attainable temperature during the campaign and at the start of the campaign a trapping temperature of $208 \mathrm{~K}$ was achieved, whilst at the end of the campaign the trapping temperature was $220 \mathrm{~K}$.

This change in the effective volume trapped did not affect the observed linearity with concentration but did reduce the sensitivity and thus the ultimate limit of detection. This could be improved with a longer trap and/or a trap with a larger surface area. At $220 \mathrm{~K}$, the precision of the instrument measuring calibrations ( $200 \mathrm{ml}$ volume at $72 \mathrm{pptv})$ over a period of $48 \mathrm{~h}$ was $4.7 \%$ (3 sigma of 48 samples), and $5.2 \%$ for 18 consecutive calibrations at $14.1 \mathrm{pptv}$.

Figure 2c shows two chromatograms obtained in Antarctica on 11th of December 2004, an air sample containing 31 pptv of PAN and an air sample with the PAN decomposed by passing the sample through the zero heater.

It is evident from Fig. 2c that the PAN is removed by passing the sample through the heated section and there is no evidence of propyl nitrate which co-elutes with PAN on this column, but is not decomposed by the heater. The small peak after PAN in the air sample in Fig. $2 \mathrm{c}$ is an unknown component that is often not present at all, but when it is present is always very small it was not present in any air samples after the zero for many hours. No other peaks in the chromatogram showed a change upon passing through the heater. Propyl nitrate was never observed in any of the zeros during this study. This is consistent with propyl nitrate measurements 
from bottle samples made regularly throughout the year at Halley being consistently below 0.2 pptv (and often below 0.05 pptv) with only a few exceptions in winter and mid summer where levels reached $1 \mathrm{pptv}$ (data not shown)

The limit of detection (LoD) of the instrument was estimated from the standard deviation of the noise of the chromatogram in the PAN region during zeros and the instrument sensitivity calculated from the calibrations, and is defined here as $3 \sigma$ of the noise.

The detection limit of the instrument varied throughout the measurement period between a minimum of $0.6 \mathrm{pptv}$ and a maximum of $4.2 \mathrm{pptv}$ with a median of 1.65 $(\mathrm{LQ}=0.89, \mathrm{UQ}=2.85)$ pptv. The causes of the drifts in instrument sensitivity are probably mostly the result of trapping temperature changes-particularly in the winter months and, because of the small size of the trap and low injection temperatures used, possible variations in the cleanliness and effectiveness of the trap caused by occasional accumulation on the trap of less volatile components. The variation in baseline noise may be due to changes in the cleanliness of the detector and the efficacy of the sample drying throughout the campaign.

The mean short-term precision, which is determined by sample-sample reproducibility and variation of instrument sensitivity between calibrations, determined from 20 sets, taken throughout the whole measurement period, of 8 consecutive air injections was $16+/-8 \%$. This was considerably worse than the precision observed for lab calibrations before and after the campaign and also worse than that observed during night-time ambient air measurements made in Norwich post-campaign (9\%). The cause of the poor precision in Antarctica is unknown.

\subsection{Field measurements}

PAN measurements were obtained from 7 July 2004 to the end of January 2005. Problems with the logging computer prior to July meant only sporadic data were obtained between March and June 2004 and these data are not included here. Samples were taken at $1 \mathrm{~h}$ intervals, calibrations were performed every 2 days and heated zeros performed every 4-5 days. Occasional blanks were also performed throughout the campaign, by sampling helium with no evidence of contamination observed at any time.

To study the long term stability of the instrument and calibration source, the calibration-derived GC sensitivity can be compared with the sensitivity of the instrument to long lived halocarbons. In our chromatograms of air (but not the calibrations) we have a few peaks which on the MxT-200 column elute earlier than PAN and are probably halocarbons. The largest and one of the latest eluting of the unknowns, peak X, is likely to be mostly $\mathrm{CCl}_{4}$. The integrated area of this peak is plotted with the calibration-derived sensitivity in Fig. 2d. The two measurements follow a very similar pattern over periods of a few days and also have the same longer term vari-
Table 1. Statistical overview of PAN mixing ratios (in pptv) during CHABLIS. The Data for Feb 99 measured at Neuymayer (Jacobi et al 2000) is included for comparison. Means and medians are calculated from the hourly data using $0.5^{*}$ est LoD for periods where PAN was below the LoD.

\begin{tabular}{lllll}
\hline Period & mean & std. dev. & Median & $\mathrm{n}$ \\
\hline All & 9.3 & 7.9 & 7.3 & 3014 \\
July & 13.2 & 9.5 & 10.3 & 364 \\
Aug & 10.2 & 7.1 & 8.7 & 461 \\
Sep & 10.4 & 8.6 & 8.9 & 413 \\
Oct & 8.0 & 4.7 & 7.4 & 413 \\
Nov & 7.1 & 4.9 & 6.8 & 465 \\
Dec & 5.5 & 3.9 & 4.6 & 441 \\
Jan & 11.1 & 8.7 & 8.0 & 457 \\
Feb (1999) & 13 & 7 & & \\
\hline
\end{tabular}

ations suggesting that we are witnessing changes in the GC sensitivity rather than changes in the calibrator output. It is clear from Fig. $2 d$ that the relative magnitudes of the peak X area and sensitivity measurements vary over the short term, but it must be recognised that there are large uncertainties regarding peak $\mathrm{X}$ such as its sensitivity to trapping conditions, its resolution from other closely eluting components and a poor baseline in the early part of the chromatogram, all of which will contribute to the variation. Over the last 3 months of the campaign, there is a gradual decrease in the mean ratio of calibration sensitivity to peak $\mathrm{X}$ area. This may be caused by a change in calibrator output leading to a maximum potential overestimation of PAN of $10 \%$ in January, but equally it could be changes in peak $\mathrm{X}$ area that are responsible for this drift.

A time series of the hourly PAN measurements and the daily mean PAN mixing ratio is shown in Fig. 3 along with hourly data for CO, ozone, temperature, TUV calculated solar flux (as a guide to potential photochemically active radiation) and $\Sigma \mathrm{C}_{2}-\mathrm{C}_{5}$ alkenes. Table 1 shows a statistical overview of the PAN data and includes the February 1999 measurements of Jacobi et al. (2000), for comparison. Where samples were below the LoD of the instrument a value of half the LoD at that time was used in the calculation of the daily and monthly averages shown in both Table 1 and Figs. 3 and 4.

The daily mean PAN mixing ratio varied from $0.82 \mathrm{pptv}$ to $33.2 \mathrm{pptv}$, whilst the individual hourly measurements ranged from below 0.6 pptv (lowest LoD) to 52.3 pptv (observed on 27 July.). Throughout the measurement period $17 \%$ of the individual hourly measurements were below the detection limit of the instrument and 23\% were lost through instrument problems-mostly in groups of 2-3 days.

There was no example of a diurnal variation in PAN observed at any time during the measurement period and the variation in the mixing ratios typically took place over periods of several days to a week. 

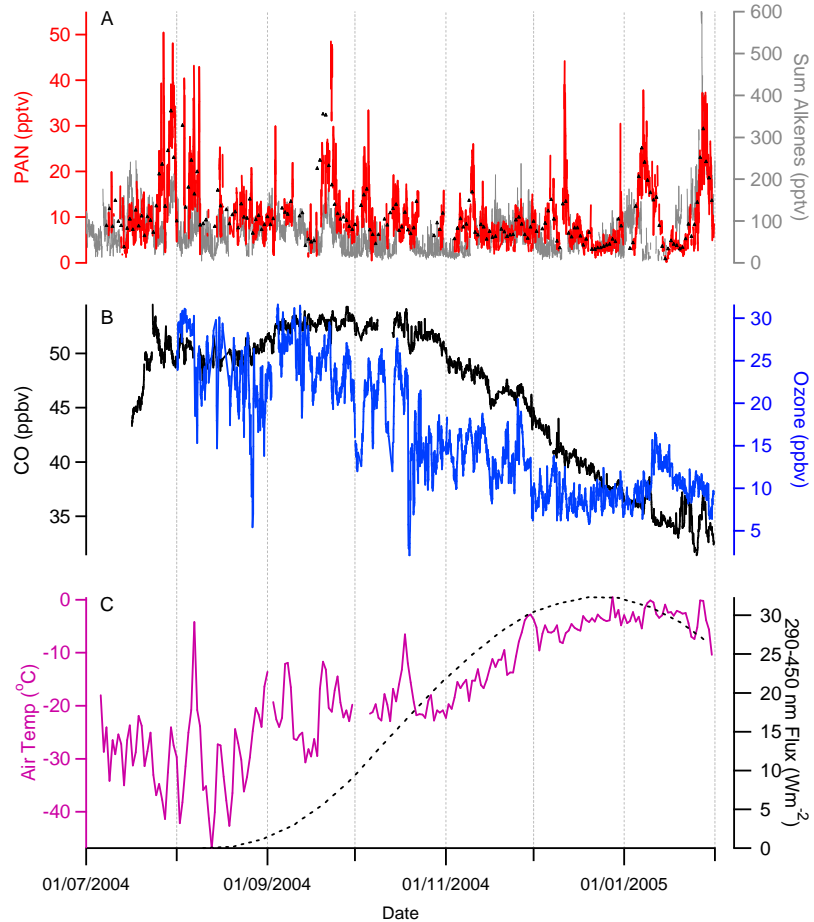

Fig. 3. Timeseries of data from Halley from July 2004 to Feb 2005 showing (A) hourly PAN measurements (red line), daily mean PAN mixing ratios (black triangles) and the $\Sigma \mathrm{C}_{2}-\mathrm{C}_{5}$ alkenes. (B) Ozone (blue) and $\mathrm{CO}$ (black) hourly measurements. (C) Hourly air temperature (red) and TUV calculated irradiation $(290-450 \mathrm{~nm}$ ) as a guide to photochemically active radiation.

The PAN mixing ratios observed in this study are consistent with those obtained at Neumayer, which is also a coastal site, by Jacobi et al. (2000) in February 1999, when a mean mixing ratio of 13 pptv was reported, with a maximum value of $48 \mathrm{pptv}$. The levels seen at Halley are somewhat lower than PAN levels typically observed in the MBL in the Southern Ocean and South Atlantic in early March (Jacobi and Schrems, 1999) though it is recognised that our data was obtained earlier in the season than those obtained in the South Atlantic. They are also much lower than the mixing ratios observed at Ny-Ålesund, Svalbard $\left(78.9^{\circ} \mathrm{N}, 11.9^{\circ} \mathrm{E}\right)$ in the comparable arctic seasons (Beine and Krognes 2000) and those seen at Alert, Nunavut $\left(82.5^{\circ} \mathrm{N}, 62.5^{\circ} \mathrm{W}\right)$ and Summit, Greenland $\left(72.5^{\circ} \mathrm{N}, 38.4^{\circ} \mathrm{W}\right)($ Dassau et al., 2004). This is not surprising given the much greater distances from sources of pollution in Antarctica compared to the Arctic and the lower levels of PAN precursors in the southern hemisphere in general.

A linear regression of the daily means of PAN and ozone shows no correlation and the short -term variation of PAN in this study does not correlate with ozone or $\mathrm{CO}$, though there is one occasion (24 to 31 January) where PAN correlates well with CO. This is in sharp contrast with a long term study of
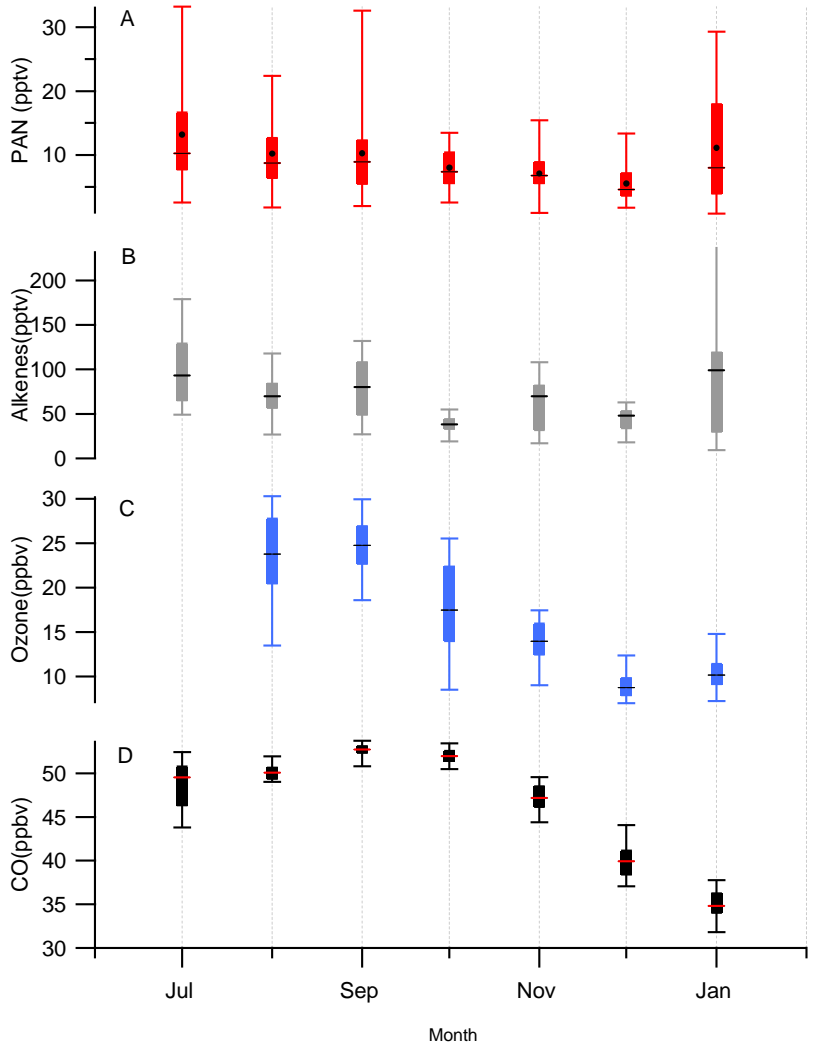

Fig. 4. Box and whisker plot showing seasonal variability of (A) PAN, (B) $\Sigma \mathrm{C}_{2}-\mathrm{C}_{5}$ alkenes, (C) ozone and (D) $\mathrm{CO}$ for each calendar month. There was no ozone data for July. The horizontal line is the median, the box represents the upper and lower quartiles and the whiskers show the maximum and minimum daily means for that month. The alkene maximum in January was $>500$ pptv and is off scale. For PAN, the monthly mean is also plotted as black circles.

PAN in the Arctic at Ny-Ålesund where ozone and PAN were highly correlated throughout the year (Beine and Krognes; 2000). The PAN, ozone and alkene data all show short term variability and whilst there is no relationship between PAN and ozone variability, there are several periods where PAN and the alkenes vary in a very similar way for long periods (e.g. 21 January 2005-31 January 2005). There are also periods where large changes in one species are not matched by changes in the other (31 December 2004-14 January 2005 is a good example).

Several studies have shown a clear seasonal cycle in the arctic with a spring maximum in PAN and a summer minimum. The monthly medians of PAN, ozone and $\mathrm{CO}$ are plotted in Fig. 4 and whilst $\mathrm{CO}$ and ozone show clear seasonal variability, with a September maximum for $\mathrm{CO}$ and ozone (although we do not have data for earlier in the year) the pattern in PAN is less clear. Whilst the observed median PAN concentrations are highest in winter and lowest in summer, and although the median PAN and ozone values follow a very 
Table 2. Rate constants and concentrations used in calculations. First order rate constants are in $\mathrm{s}^{-1}$ and $2^{\text {nd }}$ order are in molec $\mathrm{cm}^{3} \mathrm{~s}^{-1}$. Photolysis rates are calculated from TUV and $\mathrm{NO} / \mathrm{NO}_{2}$ is calculated from the Leighton relationship.

\begin{tabular}{|c|c|c|}
\hline Species & Mixing ratio used & Source \\
\hline [Ethane] & observed & Read et al. (2007) \\
\hline$[\mathrm{OH}]$ & $\begin{array}{l}\text { scaled to Jan mean of } \\
4 \times 10^{5} \mathrm{molec}^{-3}\end{array}$ & Bloss et al. (2007) \\
\hline$\left[\mathrm{HO}_{2}\right]$ & $\begin{array}{l}\text { scaled to Jan mean of } \\
0.76 \mathrm{pptv}\end{array}$ & Bloss et al. (2007) \\
\hline Temperature & observed & P. Anderson, BAS \\
\hline $\mathrm{O}_{3}$ & observed & A.Jones, BAS \\
\hline NOx & $25 \mathrm{pptv}$ & S.Bauguitte, BAS \\
\hline $\mathrm{NO} / \mathrm{NO}_{2}$ & calculated & - \\
\hline Reaction & Rate Constant & \\
\hline $\begin{array}{l}\text { Ethane }+\mathrm{OH} \rightarrow \mathrm{CH}_{3} \mathrm{CHO} \\
\left(\mathrm{k}_{1}\right)\end{array}$ & $6.9 \times 10^{-12} \exp (-1000 / \mathrm{T})$ & Atkinson et al., 2006 \\
\hline $\mathrm{CH}_{3} \mathrm{CHO}+\mathrm{OH} \rightarrow \mathrm{PA}\left(\mathrm{k}_{3}\right)$ & $4.4 \times 10^{-12} \exp (365 / \mathrm{T})$ & $\begin{array}{l}\text { Sivakumaran and Crowley, } \\
2003\end{array}$ \\
\hline $\mathrm{PAN} \rightarrow \mathrm{PA}+\mathrm{NO}_{2}\left(\mathrm{k}_{D}\right)$ & $5.4 \times 10^{16} \exp (-13830 / \mathrm{T})$ & Roberts and Bertman., 1992 \\
\hline $\mathrm{PA}+\mathrm{NO}_{2} \rightarrow \mathrm{PAN}\left(\mathrm{k}_{4}\right)$ & $1.2 \times 10^{-11}(\mathrm{~T} / 300)^{-0.9}$ & Bridier et al. (1991) \\
\hline $\mathrm{PA}+\mathrm{HO}_{2} \rightarrow$ products $\left(\mathrm{k}_{6}\right)$ & $5.2 \times 10^{-13} \exp (980 / \mathrm{T})$ & Moortgat et al. (1989) \\
\hline $\mathrm{PA}+\mathrm{NO} \rightarrow$ products $\left(\mathrm{k}_{5}\right)$ & $7.5 \times 10^{-12} \exp (290 / \mathrm{T})$ & Villalta and Howard, 1996 \\
\hline $\mathrm{O}_{3}+\mathrm{NO} \rightarrow \mathrm{NO}_{2}+\mathrm{O}_{2}$ & $1.4 \times 10^{-12} \exp (-1310 / \mathrm{T})$ & Atkinson et al. (2004). \\
\hline $\mathrm{J}_{\mathrm{CH} 3 \mathrm{CHO}} \rightarrow$ products & $2.8 \times 10^{-6}$ & calculated \\
\hline
\end{tabular}

similar pattern, the much greater day to day variation in PAN mixing ratios means that any seasonal cycle inferred from these data alone are tentative. The alkene data presented here for the July to January period show no clear seasonal pattern, but the full cycle peaks in April-May with a sharp decline into July (Read et al., 2007)

For the measurement period the daily local gross production rate of PAN was estimated, in the same manner as Dassau et al. (2004), using the following simplified reaction scheme and assuming acetaldehyde was in steady state and was the only source of the PA radical.

$$
\begin{aligned}
& \mathrm{C}_{2} \mathrm{H}_{6}+\mathrm{OH} \rightarrow \mathrm{CH}_{3} \mathrm{CHO} \\
& \mathrm{CH}_{3} \mathrm{CHO}+h v \rightarrow \text { loss } \\
& \mathrm{CH}_{3} \mathrm{CHO}+\mathrm{OH} \rightarrow \mathrm{PA} \\
& \mathrm{PA}+\mathrm{NO}_{2} \rightarrow \text { PAN } \\
& \mathrm{PA}+\mathrm{NO} \rightarrow \text { loss } \\
& \mathrm{PA}+\mathrm{HO}_{2} \rightarrow \text { loss }
\end{aligned}
$$

Clear-sky photolysis rates were estimated using TUV derived actinic flux (Madronich and Flocke, 1988) and the $\mathrm{OH}$ and $\mathrm{HO}_{2}$ concentrations were estimated by scaling the measured January mean concentrations with the actinic flux using the same method as Bloss et al. (2007).
NOx was assumed to be a constant 25 pptv and the $\mathrm{NO} / \mathrm{NO}_{2}$ ratio was estimated from the Leighton relationship (Leighton, 1961) using observed ozone.

Table 2 shows the source of the data and the rate constants used in the calculation of both steady state acetaldehyde and PAN production.

These calculations suggest that gross PAN production is roughly constant at approx $0.9-1$ pptv pptv $\mathrm{d}^{-1}$ throughout the spring and early summer and that in January it is only $0.6 \mathrm{pptv} \mathrm{d}^{-1}$ at Halley, though there may well be additional sources of both acetaldehyde and peroxyacetyl radicals, such as acetone, which would alter this production rate. Unfortunately no measurements of these oxygenates were made.

PAN loss rates were similarly estimated for the entire measurement period using the thermal and photoysis rate constants. Figure 5a shows the calculated thermal dissociation and photolysis rate constants throughout the measurement period, as well as the combined total rate constant.

Except in spring, when the total rate is still small, photolysis was only a minor contributor to the total PAN decomposition rate. The loss due to $\mathrm{OH}$ was an order of magnitude lower than that of photolysis and has not been considered further.

The maximum PAN loss rate was estimated using Eq. (1) and assuming that all radicals formed are lost.

$$
\frac{-d[\mathrm{PAN}]}{d t}=\left(k_{D}+J_{\mathrm{PAN}}\right)[\mathrm{PAN}]
$$



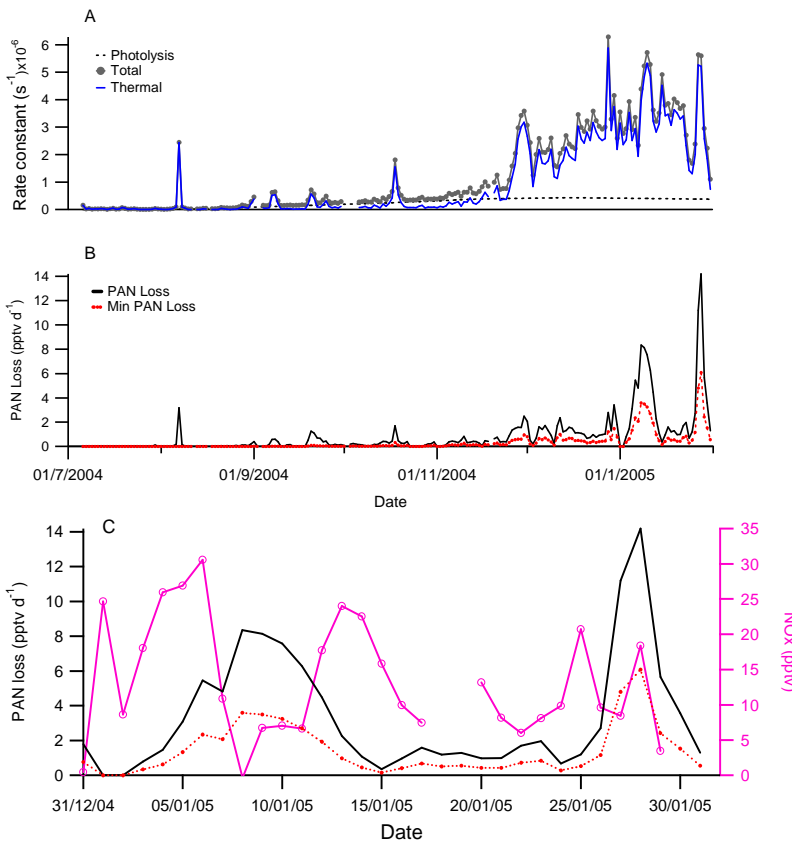

Fig. 5. (A) Calculated rate constants for PAN showing thermal dissociation (solid blue line), photolysis (dashed line) and the total (line and circle). (B) Maximum (black solid) and the minimum (red dashed) PAN loss rates calculated from equations 1 and 2, for the whole measurement period. (C) The same two PAN decomposition rates for January 2005 with the measured NOx (pink circles) also shown.

Estimates of the minimum loss rates were made by considering only the proportion of radicals formed by thermal dissociation reacting with $\mathrm{NO}$ to be lost:

$\frac{-d[\mathrm{PAN}]}{d t}=k_{D}[\mathrm{PAN}](1-\alpha)$

where

$\alpha=\frac{k_{4}}{k_{5}[\mathrm{NO}] /\left[\mathrm{NO}_{2}\right]+k_{4}}$

The resulting maximum and minimum daily PAN loss rates are shown in Fig. 5 b.

During the spring, the calculated production rates are higher than the maximum loss rates indicating that PAN production is a small net NOx sink during this period. As the season progresses, the loss rates become larger and by January, at PAN mixing ratios above about $6 \mathrm{pptv}$ the calculated minimum loss rates are greater than the estimated production rates and PAN is a net source of NOx. Measured daily mean NOx during January ranged from 6-31 pptv (shown in Fig. 5c with PAN loss rates for January only) while PAN loss rates between 4 and 14 pptv (minimum and maximum respectively) are calculated during the elevated PAN episodes. Thus PAN can be an important gas-phase source of NOx in Antarctica during the summer.
The low calculated production rates at Halley suggest that the episodes of high PAN are unlikely to have been formed locally and that the PAN has been formed elsewhere and transported to Halley (or formed in transit over a period of many days). It is, however, impossible to rule out local, sporadic sources of PAN or its precursors as a cause of these episodes.

The source regions of PAN are however impossible to determine. The PAN mixing ratio does not show any relationship to the type of back trajectory in any period of the year nor do the short - term variations correspond to changes in either ozone or $\mathrm{CO}$, which is different to the pattern seen in the Arctic (Beine and Krognes, 2000) where PAN and ozone are co-transported from mid latitudes. Other common tracers such as acetylene/CO ratios are uninformative since throughout the early part of the campaign the ratio decreases smoothly with season with no significant deviations and during late spring and summer acetylene, like several of the hydrocarbons is often below detection limit.

The absence of large deviations from the smooth seasonal change in $\mathrm{CO}$ suggests that the air sampled at Halley was well mixed, aged air with background levels of $\mathrm{CO}$ and that transport of polluted air is a rare event.

The absence of any clear relationship between recent airmass history and PAN is evident from Fig. 6, where Fig. 6a shows 8-day back trajectories for days when the daily mean PAN mixing ratio was greater than $140 \%$ of the monthly mean level, and Fig. 6b shows trajectories for days when PAN was less than $60 \%$ of the monthly mean. The data show that trajectories that originate over the sea are typically low level and those from the continent, by necessity are higher, but that there is no obvious difference between the patterns of the trajectories for high and low PAN, nor any significant difference between mean PAN mixing ratios measured in marine or continental trajectories. The data are taken from the entire measurement period, but there is still no obvious relationship between trajectory type and PAN even when viewed on a monthly or seasonal basis.

This lack of a relationship between the apparent recent airmass history and PAN mixing ratio is not entirely surprising since under high latitude conditions the lifetime of PAN can be much longer than the calculable length of a trajectory, even in summer, and the PAN lifetime itself is extremely sensitive to differences in temperature during transport.

While the PAN shows no relationship with backtrajectories, there is, for a notable proportion of the data, a clear qualitative relationship with the alkenes (mostly ethene and some propene). Figure 7 shows timeseries for PAN and the alkenes for such a period.

Ethene has an $\mathrm{OH}$ dependent lifetime of about 15 days under typical high latitude winter conditions and the ratio of ethene to propene is consistent with an oceanic origin of these species, though emissions from snowpack cannot be exclude as a possibility (Read et al., 2007). The clear relationship between PAN and alkenes suggests that the alkenes 
A

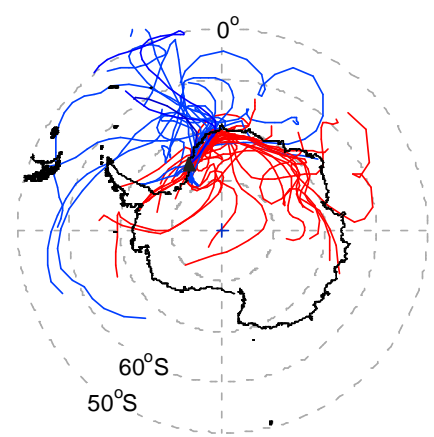

B

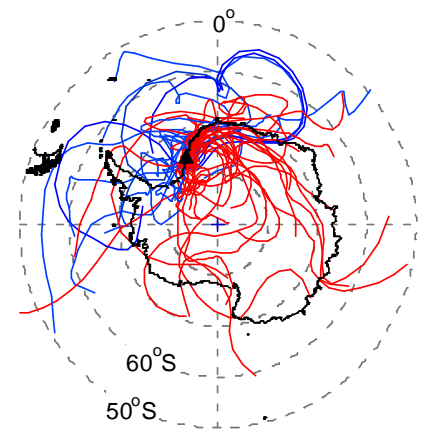

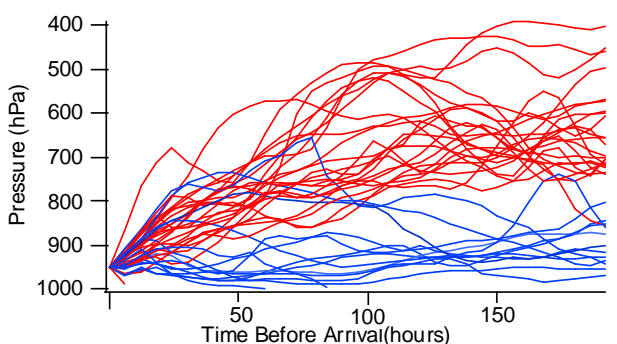

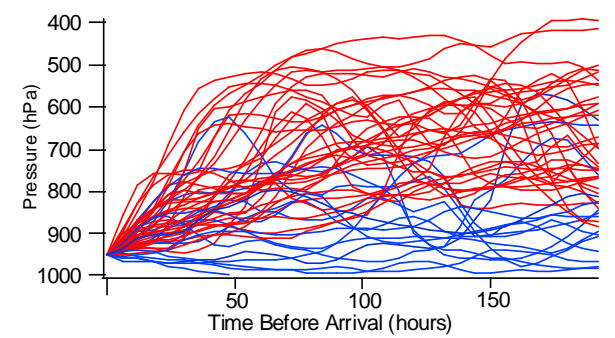

Fig. 6. Horizontal and vertical components of 8-day back trajectories (calculated using the BADC trajectory server with ECMWF analyses) for the whole measurement period where PAN mixing ratio was (A) above $140 \%$ of the monthly mean, and (B) below $60 \%$ of the monthly mean. Halley is marked by a black triangle. Blue traces show trajectories that have spent time at low levels whilst red trajectories are from higher altitudes.

and precursors of PAN share a common source and that much of the variation in PAN is caused by differing influence of oceanic emissions on the air arriving at Halley. Because of the different principal loss processes for PAN and alkenes, differences in temperature, time since emission and $\mathrm{NO} / \mathrm{NO}_{2}$ ratios will all affect the PAN/alkene ratio observed at Halley. There is again no clear relationship between back trajectory and the PAN-alkene relationship. As for the alkenes, a variable and sporadic snowpack source of either PAN or its precursors cannot be ruled out. On only one occasion is it possible to identify the potential source region. Between 25 and 30 January 2005, PAN increased and then decreased along with $\mathrm{CO}$ and alkenes with maxima occurring on 27 and 28 January. During this period, 8-day back trajectories suggest that the airmass arrived at Halley from the South Atlantic marine boundary layer (MBL) near the Falkland Islands, whist on the 26th and 30th, the air was descending from high altitudes above the Antarctic continent. Even in this period an ozone increase was not observed and during this period, there was no change in NOx, nor the sum of $\mathrm{C}_{2}-\mathrm{C}_{5}$ alkanes. This trajectory was the furthest north in the summer, but apart from this, does not stand out as unique when compared to the rest of the data

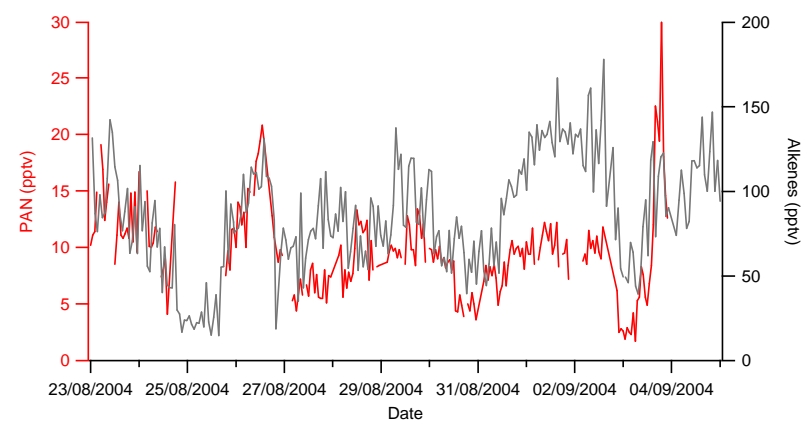

Fig. 7. Timeseries of PAN and $\Sigma \mathrm{C}_{2}-\mathrm{C}_{5}$ alkenes showing very similar patterns of variation for both species. This is one example of several such periods throughout the measurement period.

The PAN mixing ratios we observe are not incompatible with those of the surrounding region, with the July mean value at Halley being very similar to the few observations made in Punta Arenas, Chile, during June (Rudolph et al., 1987) and the South Atlantic measurements in late summer (Jacobi and Schrems, 2000) fit well with our higher observations. Mid-tropospheric air in remote regions (the $\mathrm{Pa}$ cific being the most widely studied) has been observed to 
often contain higher levels of PAN than the boundary layer (Roberts et al., 2004; Kotchenruther et al., 2001) though in these studies there was greater variation in mixing ratios at a given altitude than between different altitudes. Thus midtropospheric air transported to Antarctica could also often contain high levels of PAN.

\section{Conclusions}

The instrument as used at Halley worked well with detection limits as low as $0.6 \mathrm{pptv}$ achieved in the field. The system was also reliable for the 7 months of its active deployment thus allowing good data coverage within this period. The main limitations of the instrument are the frequency of sampling and the variations in the precision and sensitivity of the instrument in the Antarctic. An increase in trap size, using a packed trap with a much larger surface area, and an improvement in temperature control should help with the latter issues.

The measurements made in this study show that there is a possible seasonal cycle in PAN which is different to those typically observed in the Arctic and the absolute levels of PAN are much lower than observed in the Arctic during the equivalent season. Although the data presented here are not a complete annual cycle, the cycle appears to peak in winter, but the obvious relationship with alkenes (which are highest in autumn/early winter) means that an autumn maximum can not be ruled out.

In summer, the decomposition of PAN can be an important source of NOx in the Antarctic, whilst at other times of the year PAN decomposition is negligible.

Acknowledgements. We would like to thank UFAM (Universities' Facility for Atmospheric Measurement of the National Centre for Atmospheric Science (UK)) for the use of the PAN instrument and A. Jones for the use of the ozone data. Finally we would like to thank the technical and logistical staff at BAS and in particular those at Halley without whose help this work would not have been possible.

This work was funded by The Natural Environment Research Council under the Antarctic Funding Initiative, grant number NER/G/S/2001/00550.

Edited by: J. Lee

\section{References}

Atkinson, R., Baulch, D. L., Cox, R. A., Crowley, J. N., Hampson, R. F., Hynes, R. G., Jenkin, M. E., Rossi, M. J., and Troe, J.: Evaluated kinetic and photochemical data for atmospheric chemistry: Part 1 - gas phase reactions of Ox, HOx, NOx and SOx species, Atmos. Chem. Phys., 4, 1461-1738, 2004

Atkinson, R., Baulch, D. L., Cox, R. A., Crowley, J. N., Hampson, R. F., Hynes, R. G., Jenkin, M. E., Rossi, M. J., and Troe, J.
Evaluated kinetic and photochemical data for atmospheric chemistry: Volume II - gas phase reactions of organic species, Atmos. Chem. Phys., 6, 3625-4055, 2006

Barker, J. R., Benson, S. W., Mendenhall, G. D., and Goldern, D. M.: Measurement of rate constants of importance in smog, Rep. PB-274530, Natl. Tech. Inf. Serv., Springfield, Va., 1977.

Beine, H. J. and Krognes, T.: The seasonal cycle of peroxyacetyl nitrate (PAN) in the European Arctic, Atmos. Environ., 34, 933940, 2000.

Bloss, W., Lee, J., Heard, D., Salmon, R., Bauguitte, S., Roscoe, H., and Jones, A.: Observations of $\mathrm{OH}$ and $\mathrm{HO}_{2}$ radicals in coastal Antarctica, Atmos. Chem. Phys., 7, 4171-4185, 2007

Bottenheim, J. W. and Gallant, A. J.: PAN over the Arctic; Observations during AGASP-2 in april 1986, J. Atmos. Chem., 9 , 301-316, 1989

Bridier, I., Caralp, F., Loirat, H., Lesclaux, R. Veyret, B., Becker, K. H., Reimer, A., and Zabel, F.: Kinetic and theoretical studies of the reactions $\mathrm{CH}_{3} \mathrm{C}(\mathrm{O}) \mathrm{O}_{2}+\mathrm{NO}_{2}+\mathrm{M}=\mathrm{CH}_{3} \mathrm{C}(\mathrm{O}) \mathrm{O}_{2} \mathrm{NO}_{2}+\mathrm{M}$ between 248 and $393 \mathrm{~K}$ and between 30 and 760 Torr., J. Phys. Chem., 95, 3594, 1991.

Brough, N., Reeves, C. E., Penkett, S. A., Dewey, K., Kent, J., Barjat, H., Monks, P. S., Ziereis, H., Stock, P., Huntrieser, H., and Schlager, H.: Intercomparison of aircraft instruments on board the C-130 and Falcon 20 over southern Germany during EXPORT 2000, Atmos. Chem. Phys., 3, 2127-2138, 2003, http://www.atmos-chem-phys.net/3/2127/2003/.

Crutzen, P. J.: The role of $\mathrm{NO}$ and $\mathrm{NO}_{2}$ in the chemistry of the troposphere and the stratosphere, Ann. Rev. Earth Planet. Sci., 7, 443-472, 1979.

Dassau, T. M., Shepson, P. B., Bottenheim, J. W., and Ford, K. M.: Peroxyacetyl nitrate photochemistry and interactions with the arctic surface, J. Geophys. Res., 109, D18302, doi:10.1029/2004JD004562, 2004.

Flocke, F. M., Weinheimer, A. J., Swanson, A. L., Roberts, J. M., Schmitt, R., and Shertz, S.: On the measurement of PANs by Gas Chromatography and Electron Capture Detection., J. Atm. Chem 52, 19-43, 2005.

Gaffney, J. S., Marley, N. A., Cunningham, M. M., and Doskey, P. V.: Measurements of peroxyacyl nitrates (PANS) in Mexico City: Implications for megacity air quality impacts on regional scales, Atmos. Environ., 33(30), 5003-5012, 1999.

Gallagher, M. S., Carsey, T. P., and Farmer, M. L.: Peroxyacetyl nitrate in the North Atlantic marine boundary layer, Global Biogeochem. Cycles, 4(3), 297-308, 1990.

Hudman, R. C., Jacob, D. J., Cooper, O. R., Evans, M. J., Heald, C. L., Park, R. J., Fehsenfeld, F., Flocke, F., Holloway, J., Hubler, G., Kita, K., Koike, M., Kondo, Y., Neuman, A., Nowak, J., Oltmans, S., Parrish, D., Roberts, J. M., and Ryerson, T.: Ozone production in transpacific Asian pollution plumes and implications for ozone air quality in California, J. Geophys. Res., 109(23), $1-14,2004$.

Jacobi, H.-W. and Schrems, O.: Peroxyacetyl nitrate (PAN) distribution over the South Atlantic ocean., Phys. Chem. Chem. Phys.1, 5517-5521, 1999.

Jacobi, H.-W., Weller, R., Jones, A. E., Anderson, P. S., and Schrems, O.: Peroxyacetyl nitrate (PAN) concentrations in the Antarctic troposphere measured during the photochemical experiment at Neumayer (PEAN'99), Atmos. Environ., 34, 5235$5247,2000$. 
Jones, A. E., Weller, R., Minikin, A., Wolff, E. W., Sturges, W. T., McIntyre, H. P., Leonard, S. R., Schrems, O., and Bauguitte, S.: Oxidized nitrogen chemistry and speciation in the Antarctic troposphere, J. Geophys. Res. D: Atmos., 104(D17), 21355 $21366,1999$.

King, J. C.: Low-level wind profiles at an Antarctic coastal station, Antarctic Science, 1(2), 169-178, 1985.

Kotchenruther, R. A., Jaffe, D. A., Beine, H. J., Anderson, T. L., Bottenheim, J. W., Harris, J. M., Blake, D. R., and Schmitt, R.: Observations of ozone and related species in the northeast Pacific during the PHOBEA campaigns, 2, Airborne observations, J. Geophys. Res., 106(D17), 20 507-20 508, 2001.

Leighton, P. A.: Photochemistry of Air Pollution, Elsevier, New York, 1961.

Madronich, S. and Flocke,S.: The role of solar radiation in atmospheric chemistry, in: Handbook of Environmental Chemistry, edited by: Boule, P., Springer_Verlag, Heidelberg, pp. 1-26, 1988.

Moortgat, G. K., Veyret, B., and Lesclaux, R.: Kinetics of the reaction of $\mathrm{HO}_{2}$ withCH${ }_{3} \mathrm{C}(\mathrm{O}) \mathrm{O}_{2}$ in the temperature range 253368 K, Chem. Phys. Lett., 160, 443, 1989.

Muller, K. P. and Rudolph, J.: Measurements of peroxyacetylnitrate in the marine boundary layer over the Atlantic, J. Atmos. Chem., 15, 361-367, 1992.

Rappengluck, B., Oyola, P., Olaeta, I., and Fabian, P.: The evolution of photochemical smog in the Metropolitan Area of Santiago de Chile, J. Appl. Meteorol., 39(3), 275-290, 2000.

Read, K. A., Lewis, A. C., Salmon, R. A., Jones, A. E., and Bauguitte, S.: $\mathrm{OH}$ and halogen atom influence on the variability of nonmethane hydrocarbons in the Antarctic Boundary Layer, Tellus, 59B, 22-38. 2007.

Renfrew, I. A. and Anderson, P. S.: The surface climatology of an ordinary katabatic wind regime in Coats Land, Antarctica, Tellus, Ser. A: Dyn. Meteorol. Oceanogr., 54(5), 463-484, 2002.

Ridley, B. A., Shetter, J. D., Walega, J. G., Madronich, S., Elsworth, C. M., Grahek, F. E., Fehsenfeld, F. C., Norton, R. B., Parrish, D. D., Huebler, G., Buhr, M., Williams, E. J., Allwine, E. J., and Westberg, H. H.: The behavior of some organic nitrates at Boulder and Niwot Ridge, Colorado, J. Geophys. Res., 95, 13949 $13961,1990$.
Roberts, J. M.: Atmospheric chemistry of organic nitrates, Atmos. Environ., 24A, 243-287, 1990.

Roberts, J. M. and Bertman, S. B.: The thermal decomposition of peroxyacetic nitric anhydride (PAN) and peroxymetacrylic nitric anhydride (MPAN), Int. J. Chem. Kinet., 24, 297-307, 1992.

Roberts, J. M., Jobson, B. T., Kuster, W., Goldan, P., Murphy, P., Williams, E., Frost, G., Riemer, D., Apel, E., Stroud, C., Wiedinmyer, C., and Fehsenfeld, F.: An examination of the chemistry of peroxycarboxylic nitric anhydrides and related volatile organic compounds during Texas Air Quality Study 2000 using groundbased measurements, J. Geophys. Res., 108(16), ACH 4-1-ACH 4-12, 2003.

Roberts, J. M., Flocke, F., Chen, G., de Gouw, J., Holloway, J. S., Hubler, G., Neuman, J. A., Nicks, D. K., Nowak, J. B., Parrish, D. D., Ryerson, T. B, Sueper, D. T., Warneke, C., Fehsenfeld, F. C.: Measurement of peroxycarboxylic nitric anhydrides (PANs) during the ITCT 2K2 aircraft intensive experiment, J. Geophys. Res., 109, D23S21, doi:10.1029/2004JD004960, 2004

Rudolph, J., Vierkorn-Rudplph, B., and Meixner, F. X.: Large-scale distribution of peroxyacetylnitrate results from the STRATOZ III flights, J. Geophys. Res., 92, 6653-6661, 1987.

Staudt, A. C., Jacob, D. J., Ravetta, F., Logan, J. A., Bachiochi, D., Sandholm, S., Ridley, B., Singh, H. B., and Talbot, B.: Sources and chemistry of nitrogen oxides over the tropical Pacific., J. Geophys. Res., 108(2),PEM 11-1-PEM 11-17, 2003.

Singh, H. B. and Hanst, P. L.: Peroxyacetyl nitrate (PAN) in the unpolluted atmosphere: an important reservoir for nitrogen oxides, Geophys. Res. Lett., 8, 941-944., 1981.

Sivakumaran, V. and Crowley, J. N.: Reaction between OH and CH3CHO Part 2. Temperature dependent rate coefficients (201348 K), Phys. Chem. Chem. Phys., 5, 106-111, 2003

Talukdar, R. K., Burkholder, J. B., Schmoltner, A.-M., Roberts, J. M., Wilson, R. R., and Ravishankara, A. R.: Investigation of the loss processes for peroxyacetyl nitrate in the atmosphere:UV photolysis and reaction with OH, J. Geophys. Res., 100(D7), 14 163-14 173, 1995.

Warneck, P. and Zerbach, T.: Synthesis of peroxyacetyl nitrate in air by acetone photolysis, Environ. Sci. Technol. 26, 74-79, 1992.

Villalta, P. W. and Howard, C. J.: Direct kinetic study of the $\mathrm{CH}_{3} \mathrm{C}(\mathrm{O}) \mathrm{O}_{2}+\mathrm{NO}$ reaction using chemical ionisation mass spectrometry, J. Phys. Chem. 100, 13 624-13 628, 1996. 